Citation: E. Frixa (2020). Food Regeneration, Substitution and Urban Consumption in Bologna. Bollettino della Società Geografica Italiana serie 14, 3 Special Issue: $73-80$. doi: 10.36253/bsgi-996

Copyright: () 2020 E. Frixa. This is an open access, peer-reviewed article published by Firenze University Press (http://www.fupress.com/bsgi) and distributed under the terms of the Creative Commons Attribution License, which permits unrestricted use, distribution, and reproduction in any medium, provided the original author and source are credited.

Data Availability Statement: All relevant data are within the paper and its Supporting Information files.

Competing Interests: The Author(s) declare(s) no conflict of interest.

\section{Food Regeneration, Substitution and Urban Consumption in Bologna}

\author{
Food regeneration, sostituzione e consumo urbano a Bologna
}

\author{
Emanuele Frixa \\ Dipartimento di Filosofia e Comunicazione (FILCOM), Alma Mater Studiorum, Univer- \\ sità di Bologna, Italy \\ E-mail: emanuele.frixa2@unibo.it
}

\begin{abstract}
This paper traces the recent transformations that have taken place in the city of Bologna to critically redefine the meaning and scope of the changes related to commerce and consumption, and including the city's more general practices and promotional rhetoric. It will show how, starting from the increase in tourism and the strategic planning and policies to render the city more attractive, the city has undergone a reconfiguration through important regeneration processes linked to food. It will highlight the limited range of political and economic values which, through new ways of regulating public space and access to consumption, have redefined the socio-spatial fabric of certain areas of the city. The processes described will trace a path for deconstructing the reductively optimistic way in which Bologna is being portrayed, which ends up producing forms of displacement and exclusion.
\end{abstract}

Keywords: urban consumption, city branding, regeneration, foodification, Bologna.

Riassunto. Il contributo ripercorre le recenti trasformazioni avvenute all'interno dello spazio urbano bolognese per ridefinire criticamente il significato e la portata dei mutamenti legati al commercio e al consumo, fino alle più generali pratiche e ai discorsi di promozione della città. Si mostrerà come a partire dall'aumento della domanda turistica e dalla strategica pianificazione delle politiche di attrattività, la città sia stata riconfigurata attraverso importanti processi di rigenerazione legati al food. Verranno evidenziati i limiti della gerarchia di valori politici ed economici che, attraverso nuove modalità di regolamentazione dello spazio pubblico e di accesso al consumo, hanno ridefinito il tessuto socio-spaziale di alcune aree della città. I processi descritti saranno la traccia su cui decostruire le rappresentazioni dell'urbano che ridotte a visioni ottimistiche finiscono con il produrre forme di sostituzione ed esclusione.

Parole chiave: consumo urbano, city branding, rigenerazione, foodification, Bologna. 


\section{Introduction}

In the last ten years the city of Bologna has undergone significant transformations that have affected its urban fabric, commercial activities and, more generally, modes of consumption. This has involved, over a short period of time, the redefinition of strategies aimed at positioning the city within a European and international context. The transformation of certain commercially related structures, such as historic markets, has been accompanied by a certain rhetoric about the city and specific city branding policies (Dinnie 2011) (Kavaratzis 2004) (Vanolo 2017). At least two main factors have determined this complex mechanism of representations and interventions concerning the urban space: first, the consequences of the crisis of some important economic assets $^{1}$ and more traditional forms of consumption and commerce; and second, the steadily increasing tourist influx. While the former has seen, since the Great Recession of 2008, a progressive redistribution in the patterns of labor and employment ${ }^{2}$, the latter, linked above all to the increase in tourism, has called for new infrastructure strategies and planning to redefine and resignify the urban space. The increased tourist influx has been fundamental in guiding intervention and revitalization policies through a series of the city's geographical plans and imaginaries (Papotti 2020). This renewal has involved closely related urban policy operations; I will focus on at least two fundamental ones: the first concerns the upgrading of infrastructure; the second the way in which the city narrates itself through defining new discursive frames and storytelling (Mager, Matthey 2015; Sandercock 2003). The first has brought about an aesthetic enhancement thanks to the high-speed railway, begun in 2008 and completed in 2013 with the inauguration of the new station designed by Arata Isozaki and Andrea Maffei. Also, in 2008 the low-cost carrier Ryanair began using Marconi Airport, paving the way for the renewal of the Terminal - between 2011 and 2013 - and a constant increase in passenger traffic ${ }^{3}$. This visible, material aspect has been followed by an equally important one which has not directly concerned infra-

\footnotetext{
${ }^{1}$ Including the exhibition sector and part of the manufacturing sector.

2 As described by the studies of the Metropolitan Government on the Province of Bologna, in 2009 there were $67.8 \%$ of the total employed in the service sector, $30.7 \%$ in industry and 1.5 in agriculture. In 2018 the percentages were redistributed, respectively, with $71.5 \%$ in the service sector, $26 \%$ in industry and $2.5 \%$ in agriculture (Comune di Bologna 2010 and Comune di Bologna 2019).

${ }^{3}$ A constant increase from 2004 to 2019, as documented by Assaeroporti's annual reports, and with the prospect of further expansion of the airport sanctioned by the go-ahead of the conference of services to the new masterplan (https://assaeroporti.com/statistiche/).
}

structure but has strongly oriented its regeneration processes.

The aim of this paper is to show how, starting with the increase in tourism and the strategic planning of beautification policies, the recent transformations of Bologna's urban space can be re-examined from a privileged perspective in order to reach a critical understanding of the significance and extent of changes related to commerce and consumption, and to include the city's more general practices and rhetoric of promotion and representation. The rapid changes in Bologna's economic and socio-spatial context over a few years redefine the city as "consumption machine" (Rossi 2017) by intervening on organizing policies linked to attractiveness and supply to new categories of visitors. For this reason, the case study presented here offers the specific features of an urban context with recognizable functions traditionally associated with Bologna as the capital of the region of EmiliaRomagna (study, commerce, hospitality), which are redefined in a short period of time (about fifteen years). Consequently, the example of Bologna becomes emblematic and ultimately shows how the commercial regeneration of large areas of the historic center and some peripheral areas has contributed to transforming the socio-spatial fabric of the city, progressively redefining the hierarchy of political and economic values that govern it.

\section{Policies, new arrivals, new rhetoric and regeneration}

The need and the opportunity for the regenerating some of its spaces and consumption processes starts from a fundamental fact: the increase in visitors. To get an idea of the impact on Bologna of the increased tourist influxes it suffices to make a quick comparison between the years 2009, 2014 and 2019. According to the data of the 2009 Report on the tourist movement and the composition of the reception infrastructure of the Emilia-Romagna Region (Regione Emilia-Romagna 2010), "tourist presences in the Municipality of Bologna were approximately $1,700,000$ (with approximately 800,555 arrivals)". The comparison with the 2014-2019 period accounts for the significant increase recorded under the peaks: it went from 2,180,000 presences in 2014 to 3,188,000 in $2019^{4}$. The almost doubling of figures in the span of a decade is at the same time the cause and effect of certain government policies and the way Bologna has been

\footnotetext{
${ }^{4}$ See the progression from the charts published on the website The numbers of metropolitan Bologna, http://inumeridibolognametropolitana.it/dati-statistici/turisti-nel-comune-e-nella-citta-metropolitana-dibologna-serie-storica
} 
represented (Rossi, Vanolo 2012). These data indicate the important role played by tourism - and consequently by commerce - and indicate the powerful connection between policies of aesthetic enhancement and economic investments in the food and restaurant sector, along with the transformation of Bologna into a new tourist destination. It is precisely these factors that have placed Bologna on the list of cities affected in recent years by touristification and tourism gentrification processes (Cocola-Gant 2018; Sequera, Nofre 2018; Gravari-Barbas, Guinand 2017; D’Eramo 2018), whose effects will be explained below.

Weaving the fabric of this connection took a powerful and effective city branding operation that provided the framework within which to refurbish plans ${ }^{5}$ and strategies aimed at reconfiguring commercial areas. The original investment came about from the need to revalue the city's resources by building an effective mechanism through which to "narrate the city to the world" (Comune di Bologna. Iperbole 13/12/2013). The Bologna City Branding 6 project, won by è Bologna, refurbished a discursive and value strategy capable of re-signifying its various representations: a true generative logo that could encompass and personalize the entire range of urban experiences ${ }^{7}$. Among these experiences, what dominated and engulfed the storytelling of the city was food: the territorial marketing project City of Food, born as a (re) generative logo connected to è Bologna, fulfilled this function. As the blurb reads on the city's website:

One of Bologna's internationally recognized elements of identification is food, not only for its gastronomic aspects, but also for the profound attention paid by various local operators and institutions to food in its various contexts: social, environmental, scientific, economic, didactic, cultural and recreational.

City of Food is a project that was created to coordinate all food initiatives by both promoting some of them directly and proposing itself as a clearing house of all the research, spaces, experiences, and scientific-cultural-commercial events related to food that take place in the metropolitan area of Bologna. Public and private partners who choose to join the initiative can contribute to promoting Bologna as a city of food at an international level (Comune di Bologna. Iperbole 24/03/2014).

\footnotetext{
${ }^{5}$ The reference is to the Piano Strutturale Comunale (Municipal Structural Plan), which entered into force in 2008 with the aim of providing "the general guidelines that will guide the city's urban development over the next twenty years" (http://www.comune.bologna.it/psc/articoli/1797).

${ }^{6} \mathrm{http} / / / \mathrm{www}$. fondazioneinnovazioneurbana.it/progetto/bolognacitybranding

${ }^{7}$ For a critical reconstruction of the genesis of the generative logo of Bologna, see Bonazzi 2019, 17-45.
}

What clearly emerges is that the response to the economic crisis had already identified, in 2012, future development vectors in food and tourism, building a specific "narrative of place" (Papotti 2020, 151) and reproducing the conditions for a new economy based on "foodtainment" (Finkelstein 1999) and more generally a new "recreational turn" (Stock 2007). Hence, with the formalization in 2014 of Bologna City of Food and the creation of the Bologna Welcome agency, the structural conditions were set up to continue investing in promoting the city and making it attractive: new visitors, new tourists, new consumers. The revenue from the tourist tax made it possible to invest in cost-free cultural activities, giving the city the perception of an inclusive spirit and shared participation ${ }^{8}$.

Together with the first goal of promoting the city as a new tourist destination, the next phase involved managing the destination and hospitality, as well as promoting authenticity through the socio-economic wealth being offered. In line with this was the commercial regeneration of some areas of the historic center, traditionally destined for market activities, such as the Mercato di Mezzo and the Mercato delle Erbe ${ }^{9}$. This new reconfiguration, by favoring the replacement of the fruit and vegetable stalls with new refreshment stands, has turned out to be a rational and successful way to make the urban space profitable by exploiting the influxes, and so guaranteeing the city's economic recovery and new strategic positioning ${ }^{10}$.

The regeneration of spaces associated with commercial replacement has been one of the most significant tools and effects for setting in motion the consumption of the city policy by placing Bologna within those processes of economic and cultural regeneration (Vicari Haddock 2009, 26-35), characterized by interventions on infrastructures, "which will serve to economically develop the area", and "by interventions of a cultural nature" (Semi 2015, 74), functional to promoting it and making it aesthetically attractive. In this respect the many possible itineraries promoted by Bologna Welcome ${ }^{11}$ are a prepackaged idea of the city, resulting from the close link between both narratives and rhetoric about the city,

\footnotetext{
${ }^{8}$ Consider, for example, important traditional initiatives such as the Cinema Ritrovato, in Piazza Maggiore, all the musical and entertainment activities related to the Biografilm Festival, or to the busy calendar of Bologna Estate.

${ }^{9}$ For a precise reconstruction of the regeneration processes applied to the two markets, see Zinzani 2019; Frixa 2019a.

${ }^{10}$ I refer in this regard to the "Mercati" section of Progetto 19: City of Food (Comune di Bologna. Iperbole (12/06/2019). In reference to the regeneration and requalification of the Mercato delle Erbe see Comune di Bologna. Iperbole 4/03/2015).

${ }^{11} \mathrm{https} / / /$ www.bolognawelcome.com/it/informazioni/ispirati
} 
and the increase in influxes associated with regeneration processes $^{12}$. These are strategies that blatantly reveal a political-economic planning that actually does not allow deviations from a translation of urban life into commodified forms of consumption. The critical interpretation of the overlap between the material transformations of the space and the policies concerning how the city is portrayed and promoted, has made it possible to identify a series of effects and consequences specifically attributable to the Bologna context.

\section{The consequences. Representations, effects, values: the price of replacement}

The effects of the overlap among city branding policies, an increase in visitors and regeneration processes linked to consumption have transformed the commercial fabric of the city and the use of space, especially as regards specific activities located in the historic center. According to tourism and trade data, for the past several years Bologna has undergone a food mania that, according to the Chamber of Commerce, has seen catering grow by $27 \%$ from 2009 to 2018 , leading to as much as a $72 \%$ increase in takeaways ${ }^{13}$. This result on the material space of commerce, linked to a remodulation of the offering in the retail and administration sectors, has clearly encouraged certain redefinitions of the city by changing its perception in recent years. It is no coincidence that the attention of the international press has often focused precisely on the new city of food, hastily skipping over what had been its most traditional geographical imaginary. Despite the fact that Bologna has been known in Italy and abroad through the label "the learned, the red and the fat", the Guardian in its Bologna city guide, had proclaimed: "but it is la grassa (the fat) that's perhaps the most fitting ${ }^{14 "}$ ". What aroused the interest of the international press, together with the result of the policies adopted and the consequent repositioning of the city as a tourist destination, had been - at the end of 2017 - the inauguration of Fico Eataly World, the largest agri-food park in the world, located in the northeast district of the city, just beyond the Pilastro district. The big operation carried out within the CAAB (Centro Agroalimentare di Bologna) by the City, Eataly, Coop Alleanza 3.0 and Prelios Sgr, was the most significant consequence of the consolidation of a pub-

\footnotetext{
12 For a critical view of the urban regeneration processes in Bologna, see Zinzani, Proto 2020.

13 The number of bars and restaurants in the historic center are 1 for every 37 inhabitants. By the way, please note the article by Lillo 2019.

${ }^{14}$ Hubbel 2017.
}

lic-private partnership in which the public sector creates the basis for the private sector to be able to operate, favoring the conditions for realizing new profits ${ }^{15}$. Thus Bologna has become the Italian and European capital of food, using the commercial regeneration of large areas of the historic center and some outlying areas as a means for significantly transforming the city's socio-spatial fabric. A Bolognese food regeneration that has temporarily obscured some of its historic attractions, as the article in the Guardian notes, paving the way for a new large "widespread space for catering and consumption" (Dansero, Nicolarea 2016, 22). A city historically linked to an imaginary and an urban activity based on university study, industrial excellences, a well-defined political tradition and a marked cultural, musical and cinematographic identity has, in the space of just a few years, been flattened into the City of Food.

The direct consequences of these policies and processes is found in another article published by the New York Times that just inside the "regenerated" Mercato delle Erbe rediscovers the new and more authentic "rebel" spirit of the city of Bologna:

\begin{abstract}
"The students who congregated nightly in piazzas have been forced to move outside the city wall, replaced with temporary visitors like me, heading to Airbnb with their roller suitcases click-clacking on cobblestone streets. That rebel spirit, though, still persists. We found it at Mercato delle Erbe, a food market by day that fills with mostly crowds of residents at drink stands by night"16.
\end{abstract}

The consequences of these promotional policies, seemingly inclusive and shared, give us an insight into a number of direct effects, as well as a specific, renewed value dimension, capable of producing dystopias through its vaunted urban images: it is in this scenario that the replacement effect exhibits its full force. In Bologna the important urban community of students seems to be marginalized in the context of redefining the hierarchies of a strongly consumer-oriented policy. Added to this is an increasingly widespread phenomenon of short-term rental platforms - for tourists and transient visitors, concentrated mainly in the historic center - as further evidence of the displacement of city users, redesigning living spaces and values in precisely the same way as it has recently done to commercial activities that no longer fit into the new rules for spatial utilization.

In line with this trend is the new "Regulation for the exercise of commerce in urban areas of cultural

\footnotetext{
15 See Mosconi 2019.

16 Yuan 2018.
} 
value" approved by the City Council on July 8, 2019, which extends to the "nucleus of ancient formation" a set of measures aimed at limiting the presence of "commercial activities incompatible with the need to protect and enhance our cultural heritage". The Municipality website lists the activities whose activation, in the wake of the "UNESCO Decree" (Legislative Decree no. 222, 25 November 2016) and the Code of Cultural Heritage and Landscape (Legislative Decree no. 42, January 22, 2004), will be banned for a three-year period (Comune di Bologna. Iperbole 12/06/2019). What clearly emerges from this decree is a will to progressively exclude certain commercial activities from much of the historic center. The intent is to impose yet another reconfiguration of the urban space in the direction of its future patrimonialization, made explicit by the presentation of the candidacy of the Portici di Bologna as a UNESCO World Heritage Site. Hence substitutions as the main effect of a "food gentrification" (Cohen 2018; Sbicca 2018), elsewhere defined as "foodification" (Frixa 2019b, 109-129; Loda et al., 2020), extended to large areas of the city, and directed towards a now consolidated "new frontier of gentrification" (González, Waley 2012; González 2018; Sequera, Nofre 2018), starting from the regeneration of historical markets and certain food-related forms and practices of consumption. In this rapid redefinition of the values that guide the city's policies, the example of Bologna therefore seems exemplary, due to the speed of the substitution processes applied to the consumer areas, as well as the premature exhaustion of the portrayals that encouraged and produced them.

\section{Conclusions. Space consumption and market risk}

But the candidacy of the Portici di Bologna as a UNESCO World Heritage Site is indeed a tangible sign of the exhaustion of the city of food ${ }^{17}$ brand and the need to refashion the city's offering and positioning on aspects mainly related to its cultural and architectural heritage. Once again, the processes described above become the engine of substantial transformations that redefine the methods of use and regulation of public space and, in some instances, of social conflict. This is the direction taken by the new Dehors regulation (regulation of the occupation of public land for outdoor spaces annexed to public administration premises), which outlines a special regulation for some areas where it is possible to adopt "guidelines and projects for managing

${ }^{17}$ Today the one on food is just one of the itineraries suggested by Bologna Welcome. outdoor spaces based on motivated needs for functionality, decorum and protection of the urban context"18. Once again the city is reconfigured to prepare for a new scenario, through new keywords and new rhetoric. The limits set for the historic center area and for some activities related to commerce, reproduce, through displacement procedures, new forms of exclusion (Cocola-Gant 2019): the activities that no longer fall within the new discursive and regulatory framework, along with the persons who cannot participate in those forms of consumption, are excluded from the representation of the city.

The quest for a personalization of the urban experience and for forms of authenticity to be delineated within the tourist influxes have ultimately contributed to shedding light on market limits that nurture a "gentrified authenticity" (Gonzalez, Waley 2012) and reproduce, in the guise of hospitality, the consumption of authenticity as a means of exclusion (Zukin 2008). Hence the most glaring result of certain territorial marketing policies did not prefigure just a rapid consumption of the effectiveness of the brand applied to the complex urban geography, but ended up reproducing, in what boasts itself as a hospitable and welcoming city (Bell 2007), the emergence of new forms of enclosure (Harvey 2012; Hodkinson 2012; Sevilla-Buitrago 2015). This, in the case of Bologna, becomes one of the major risks in sacrificing the city for market reasons and favors the emergence of new, more or less visible borders that involve not just the opening hours of public establishments or the conflict between customers and residents in some areas devoted to consumption, but justify in the name of urban decorum the very methods for exploiting public space (Loda et al. 2011) ${ }^{19}$.

The processes described, which have affected and transformed urban consumption in Bologna, show how access to consumption has ultimately become an access or exclusion from the city and how they are the contributing cause of a sudden emptying of the urban space. In the final analysis, access to consumption becomes an access or exclusion from the city, and paradoxically the risk of emptying the urban space becomes more and more concrete. As recently indicated, "the apartments where tourists stay, which are in effect subtracted from the availability pool of residents, leave an 'empty' social fabric, a 'city made of air', causing the progressive emptying out of the historic center, turning it into

\footnotetext{
${ }^{18}$ Art. 20, Area projects (Comune di Bologna 2018).

19 These aspects have been treated in a talk entitled "I confini al mercato" (Market Borders), presented at the conference "Confin(at)i/ Bound(aries), IX Giornata di Studio Oltre la globalizzazione", held in Trieste on December 13th, 2019.
} 
a showcase (Codeluppi 2014), or, to say it another way, it is sacrificed in order to create a place of transit and consumption" (Frixa 2019b, 125). The emptying out process already determined by the food brand and the apartments reserved for short-term tourist rentals, seems prophetic today, if we consider the weeks of lockdown during the Covid-19 pandemic ${ }^{20}$, and the measures currently being implemented in the second wave of the pandemic. A city set up over the last decade to attract floods of tourists finds itself alone with its residents, and before it will be able to reactivate the receptivity and tourism machine, it will have to deal with the limits of the model that promoted and governed it. For this reason, the rapid transformations described provide, in the Bologna context, a privileged perspective for understanding the reasons and limits of the changes linked to trade and consumption. This is a great opportunity to intervene on the now cyclical consumption of the urban space and its representations, and to find a middle way between market needs and the rights of residents to their city.

\section{References}

Bell, D. (2007). The Hospitable City: Social Relations in Commercial Spaces. Progress in Human Geography, 31 (1), 7-22. DOI: https://doi.org/10.1177/0309132507073526

Bonazzi, A. (2019). Bologna: breve geografia di una "città à la carte”. In Bonazzi, A., Frixa, E. (Eds.). Mercati storici, rigenerazione e consumo urbano. Il caso di Bologna. Milano, Franco Angeli, 17-46.

Bonazzi, A., Frixa, E. (Eds.). (2019). Mercati storici, rigenerazione e consumo urbano. Il caso di Bologna. Milano, FrancoAngeli.

Celata, F. (18/8/2020). Come cambieranno le città degli affitti brevi e di Airbnb dopo la pandemia. Che fare. https://www.che-fare.com/celata-citta-affitti-piattaformepandemia/

Cocola-Gant, A. (2018). Tourism Gentrification. In Lees, L., Phillips, M. (Eds.). Handbook of Gentrification Studies. Cheltenham and Northampton, Edward Elgar Publishing.

Cocola-Gant, A. (2019). Gentrification and displacement: urban inequality in cities of late capitalism. In Schwanen, T., Van Kempen, R. (Eds.). Handbook of Urban Geography. Cheltenham and Northampton, Edward Elgar Publishing, 297-310. DOI: https://doi. org/10.4337/9781785364600.00030

${ }^{20}$ For an initial critique on how short-term rental cities will change after the pandemic, see Celata 2020.
Codeluppi, V. (2014). Metropoli e luoghi del consumo. Milano-Udine, Mimesis.

Cohen, N. (27/03/2018). Feeding or Starving Gentrification: The Role of Food Policy. CUNY Urban Food Policy Institute. https://www.cunyurbanfoodpolicy.org/ news/2018/3/27/feeding-or-starving-gentrification-therole-of-food-policy

Comune di Bologna (2010) Il mercato del lavoro nel 2009: la posizione di Bologna rispetto alle altre grandi città, http://www.comune.bologna.it/iperbole/piancont/MercatoLavoroBologna/Pres_2009_\%20Lavoro.pdf

Comune di Bologna (2018), Regolamento dehors, Regolamento delloccupazione di suolo pubblico per spazi all'aperto annessi ai locali di pubblico esercizio di somministrazione, http://informa.comune.bologna.it/iperbole/media/files/nuovo_regolamentodehors_aggiornato_18_12_2018_.pdf

Comune di Bologna (2019) Il mercato del lavoro nell'area metropolitana bolognese nel 2018, http://inumeridibolognametropolitana.it/sites/inumeridibolognametropolitana.it/files/lavoro/mercato_del_lavoro_2018_0.pdf

Comune di Bologna. Iperbole (12/06/2019). Decreto Unesco, stop per tre anni a nuovi esercizi alimentari, internet point e sale slot. http://www.comune.bologna.it/news/ decreto-unesco

Comune di Bologna. Iperbole (12/06/2019). Progetto 19: City of Food. http://partecipa.comune.bologna.it/sites/ comunita/files/progetti/allegati/19_scheda_collaborareebologna_city_of_food.pdf

Comune di Bologna. Iperbole (4/03/2015). Nuove attività e riqualificazione al Mercato delle Erbe. http://www.comune.bologna.it/news/nuove-attivit-e-riqualificazione-almercato-delle-erbe

Comune di Bologna. Iperbole (13/12/2013). Bologna city branding. Il nuovo progetto per raccontare la città, http:// www.comune.bologna.it/news/bologna-city-branding-ilnuovo-progetto-raccontare-la-citt

Comune di Bologna. Iperbole (24/03/2014). City of food, il progetto di marketing territoriale sul cibo che guarda all'Expo 2015. http://www.comune.bologna.it/news/cityfood-il-progetto-di-marketing-territoriale-sul-cibo-cheguarda-allexpo-2015

D'Eramo, M. (2018). Il selfie del mondo. Indagine sull'età del turismo. Milano, Feltrinelli.

Dansero, E., Nicolarea, Y. (2016). Dalle pratiche alle politiche: costruire gli spazi del cibo. Territorio, 79, 19-26. DOI: 10.3280/TR2016-079003 
Dinnie, K. (2011). Introduction to the theory of city branding. In Dinnie, K. (Ed.). City Branding: Theory and Cases. Palgrave Macmillan, New York, 3-7.

Finkelstein, J. (1999). Foodtainment. Performance Research, 4 (1), 917-935. DOI: https://doi.org/10.1080/135281 65.1999 .10871653

Fondazione Innovazione Urbana, City of food, http:// www. fondazioneinnovazioneurbana.it/chisiamo/45uncategorised/803-presentazione-city-of-food

Frixa, E. (2019a). La rigenerazione del Mercato delle Erbe. In Bonazzi, A., Frixa, E. (Eds.). Mercati storici, rigenerazione e consumo urbano. Il caso di Bologna. Milano, FrancoAngeli, 85-107.

Frixa, E. (2019b). Città, Consumo, Spazi. In Bonazzi, A., Frixa, E. (Eds.). Mercati storici, rigenerazione e consumo urbano. Il caso di Bologna. Milano, FrancoAngeli, 109129.

González, S. (Ed.). (2018). Contested markets, contested cities: gentrification and urban justice in retail spaces. London-New York, Routledge.

González, S., Waley, P. (2012). Traditional Retail Markets: The New Gentrification Frontier? Antipode 45 (4), 965-983. DOI: https://doi.org/10.1111/j.14678330.2012.01040.x

Gravari-Barbas, M., Guinand, S. (2017). Introduction: Addressing Tourism-Gentrification Processes in Contemporary Metropolises. In Gravari-Barbas, M. Guinand, S. (Eds.). Tourism \& Gentrification in Contemporary Metropolises: International Perspectives. Abingdon, Taylor \& Francis, 1-22.

Harvey, D. (2012). Rebel Cities. From the Right to the City to the Urban Revolution. London-New York, Verso Book.

Hodkinson, S. (2012). The New Urban Enclosures. City, 16 (5), 500-518. DOI: https://doi.org/10.1080/13604813.2 012.709403

Hubbel, D. (21/10/2017). Bologna city guide: what to see plus the best bars, restaurants and hotels. The Guardian. https://www.theguardian.com/travel/2017/oct/21/ bologna-italy-city-guide-best-bars-restaurants-hotels-museums-art

I numeri di Bologna metropolitana, Dati statistici, http:// inumeridibolognametropolitana.it/dati-statistici/turistinel-comune-e-nella-citta-metropolitana-di-bologna-seriestorica

Kavaratzis, M. (2004). From city marketing to city branding: Towards a theoretical framework for developing city brands. Place Brand Public Dipl, 1, 58-73. DOI: https:// doi.org/10.1057/palgrave.pb.5990005

Lillo, N. (15/04/2019). Airbnb e ristoranti stravolgono le città: “C’è rischio bolla". La Stampa. https://www.lastampa. it/topnews/primo-piano/2019/04/15/news/airbnb-e-ristoranti-stravolgono-le-citta-c-e-rischio-bolla-1.33695372

Loda, M., Aru, S., Barsotelli, M., Sbardella, S. (2011). I dehors fra erosione dello spazio pubblico e nuove forme di convivialità. In Loda, M., Hinz, M. (Eds.). (2011). Lo spazio pubblico urbano: teorie, progetti e pratiche in un confronto internazionale. Pisa, Pacini, 83-103.

Loda, M., Bonati, S., Puttilli, M. (2020). History to eat. The foodification of the historic centre of Florence. Cites, 103. DOI: https://doi.org/10.1016/j.cities.2020.102746

Loda, M., Hinz, M. (Eds.). (2011). Lo spazio pubblico urbano: teorie, progetti e pratiche in un confronto internazionale. Pisa, Pacini.

Mager, C., Matthey L. (2015). Tales of the City. Storytelling as a contemporary tool of urban planning and design. Articulo - Journal of Urban Research [Online], Special issue 7. DOI: https://doi.org/10.4000/articulo.2779

Mosconi, F. (2019). Fico: perché a Bologna. In Montanari, M. (Ed.). Alla bolognese. Dalla città grassa a Fico. Bologna, il Mulino, 179-200.

Papotti, D. (2020). Immaginari geografici e marketing turistico: dal "brand territoriale" ai "paesaggi griffati". Ri-Vista, 17 (2), 146-157. DOI: https://doi.org/10.13128/ rv-8320

Regione Emilia-Romagna (2010). Rapporto annuale sul movimento turistico e la composizione della struttura ricettiva (alberghiera e complementare) dell'Emilia Romagna. Servizio turismo e qualità aree turistiche, https://imprese. regione.emilia-romagna.it/turismo/doc/documenti/statistiche-sul-movimento-turistico-regionale

Rossi, U. (2017). Cities in global capitalism. Cambridge, Malden (MA), Polity.

Rossi, U., Vanolo, A. (2012). Urban Political Geographies: A Global Perspective. London, Sage.

Sandercock, L. (2003). Out of the Closet: The Importance of Stories and Storytelling in Planning Practice. Planning Theory \& Practice, 4 (1), 11-28. DOI: https://doi. org/10.1080/1464935032000057209

Sbicca, J. (2018). Food, Gentrification, and the Changing City. BOLETÍN ECOS, 43, 1-21.

Semi, G. (2015). Gentrification. Tutte le città come Disneyland? Bologna, il Mulino. 
Sequera, J., Nofre, J. (2018). Shaken, not stirred, City, 22 (5-6), 843-855. DOI: https://doi.org/10.1080/13604813.20 18.1548819

Sevilla-Buitrago, A. (2015). Capitalist Formations of Enclosure: Space and the Extinction of the Commons. In Antipode, 47 (4), 999-1020. DOI: https://doi.org/10.1111/ anti.12143

Stock, M. (2007). European Cities: Towards a Recreational Turn? Hagar: Studies in Culture, Polity and Identities, 7 (1), 115-134.

Vanolo, A. (2017). City Branding. The Ghostly Politics of Representation in Globalising Cities. London, Routledge.

Vicari Haddock, S. (2009). La rigenerazione urbana: un concetto da rigenerare. In Vicari Haddock, S., Moulaert F. (Eds.). Rigenerare la città. Pratiche di innovazione sociale nelle città europee. Bologna, il Mulino, 19-50.

Yuan, J. (2/10/2018). The 52 Places Traveler: Two Versions of the Slow Life in Central and Southern Italy. The New York Times. https://www.nytimes.com/2018/10/02/ travel/52-places-bologna-and-matera-italy.html

Zinzani, A. (2019). La rigenerazione del Quadrilatero e del Mercato di Mezzo. In Bonazzi, A., Frixa, E. (Eds.). Mercati storici, rigenerazione e consumo urbano. Il caso di Bologna. Milano, FrancoAngeli, 47-83.

Zinzani, A., Proto M. (2020). L’emergere del Political nei processi di rigenerazione urbana a Bologna: movimenti e spazi di dissenso. Geotema. Supplemento 2020, 45-54.

Zukin, S. (2008). Consuming authenticity: From outposts of difference to means of exclusion. Cultural Studies, 22 (5), 724-748. DOI: https://doi. org/10.1080/09502380802245985 